\title{
Carta de don Jerónimo de Contreras, corregidor de Atacama, a la Real Audiencia de La Plata, proponiendo las mejores medidas de calmar la sublevación de los indios del dicho lugar
} ANB. C. 1638 , III, $22 \mathrm{~N}^{\circ} 1455$, fs. 2

Transcripción de José LuIs MarTínez.

[f. 1r]

[crismon]

Atacama, 22/3 1638

Muy Poderoso Señor

[Al margen: Estas cartas se rrecivieron oy sabado diez y siete de abril de 63 años y se mandó que estando aqui don Pedro Liquitaya sea puesto en la carcel]

[rubricado]

La carta que rremito a V.A. es de Joan Cavallero Alguaçil mayor del Santo Oficio en esta Prouinçia persona muy selosa del Real Seruiçio como lo muestra en la dicha carta rreçiuila oy dia de la fecha y por ser el casso de tanta inportançia la despacho al punto yo no e querido haçer ninguna diligençia porque no e sentido nunca nada en los indios de Atacama la Alta y por no alterar la cosa asta tener orden de V.A. si bien estoy con cuydado y a la mira. Pareceme que si se puede dar algun credito a lo que se rrefiere en dicha carta la causa que los dichos indios tubieron fue la que les dió don Pedro Liquitaya gouernador que a sido suyo al qual por petiçion de los curas desta prouinçia quite la cobransa y administraçion que tenia de los tributos rreales como tal gouernador y auiendole tomado cuenta de ellos y alcansado en cantidad de pesos, le prendi asta que los enterase el qual se huyó de la priçion y para que fuese buelto a ella despache rrequisitoria en este intermedio tube notiçias de que el dicho Pedro Liquitaya era el saçerdote mayor de la idolatria y auiendole echo la causa rresultó grauemente culpado por lo qual le condene a muerte en rrebeldia como todo consta de los vnos y otros autos a que me rrefiero tambien me parese que el dicho don Pedro Liquitaya como hombre obstigado [sic] y que se sentia tan culpado pensando librarse derramó esta bos y que los indios no son parte //

\section{[f. 1v]}

en semejante casso si bien como jente facil puede ser que si el dicho don Pedro Liquitaya boluiese a esta prouinçia tan apartada y tan poco o nada abitada de españoles y que confina con la de los calchaquies todo sesaria con que pues el dicho don Pedro Liquitaya esta en esa ciudad que passó con el maestro Joan de Alçala vecino de los curas desta prouinçia mandase V.A. prenderle y poner el remedio que a V.A. le paresiere y fuere seruido en esta conformidad y por si acasso sin pareçer el dicho don Pedro Liquitaya en esa çiudad rretrosediere e dado abiso a vuestros corregidores de Potossi y Lipes encargandoles no se dibulgue porque no llegue a su noticia y se procure ocultar.

Guarde Dios a V. A. Atacama 22 de marzo de 1638

Don Geronimo de Contreras [rúbrica] 